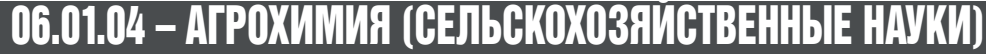

\section{МИНЕРАЛЬНЫЕ УДОБРЕНИЯ В ТЕХНОЛОГИИ ВОЗДЕЛЫВАНИЯ ЯРОВОЙ ПШЕНИЦЫ В УСЛОВИЯХ СРЕДНЕГО ПОВОЛЖЬЯ}

Захаров Николай Григорьевич, кандидат сельскохозяйственных наук, доцент кафредры «Почвоведение, агрохимия и агроэкология»

Хайртдинова Наталья Александровна, кандидат сельскохозяйственных наук, доцент кафедры «Почвоведение, агрохимия и агроэкология»

ФГБОУ ВО УльянОвскИй ГАУ

432017, г. Ульяновск, бульвар Новый Венеи, 1; тел.: 8(8422) 55-95-68; e-mail: agroec@yandex.ru

Ключевые слова: яровая пшеница, минеральные удобрения, клейковина, индекс деформации клейковины, урожайность.

В работе приведены результаты изучения эффективности минеральных удобрений в технологии возделывания яровой пшеницы. Экспериментальные исследования проведены на опытном поле ФГБОУ ВО Ульяновского ГАУ в 2017-2020 гг. в пятипольном зерновом сидеральном севообороте: пар сидеральный - озимая пшеница - яровая пшеница - соя - ячмень. В опыте изучали изменение урожайности и качества зерна яровой пшеницы сорта Ульяновская 100. Математическая обработка данных показала, что достоверная прибавка урожайности зерна яровой пшеницы обеспечивалась на вариантах с дозой внесения удобрений 40 и 60 кг/га д.в., которая составляла 0,57 m/га и 0,73 m/га соответственно. При этом наблюдалось увеличение количества клейковины до 27,8 \% и улучшение ее качества на варианте с применением удобрений в дозе 60 кг/га д.в. (73 единии ИДК), что относит ее к І группе качества. Проведенный корреляционно-регрессионный анализ позволил выявить зависимости между урожайностью зерна яровой пшеницы и условиями ее формирования. Выявлена прямая зависимость между урожайностью и фоном питания культуры ( $r=0,64)$. Важно отметить, что основным фрактором, влияющим на накопление клейковины в зерне, являются условия минерального питания растений $\left(R^{2}=0,55\right)$, коэффрициент детерминации зависимости накопления клейковины от ГТК составил $R^{2}=0,26$. Результаты исследований показали наличие тесной связи между массовой долей клейковины и белка в зерне яровой пшеницы сорта Ульяновская $100\left(R^{2}=0,70\right)$. Накопление белка в урожае в годы исследований изменялось от 264 (контроль) до 509 кг/га $\left(N_{60} P_{60} K_{60}\right)$.

\section{Введение}

Пищевые продукты, производимые из зерна, являются повседневно востребованными, обеспечивая до 40 \% калорийности рациона человека и от 40 до 50 \% потребляемых им белков и углеводов. Как следствие, показатель потребления зерна является одним из основных критериев продовольственной безопасности страны. Яровая пшеница по продуктивности уступает озимой пшенице, именно ей принадлежит доминирующая роль в структуре зернового клина [1].

Лесостепная зона относится к лидирующим регионам по возделыванию яровой пшеницы. Несмотря на то, что посевные площади этой культуры в регионе расширяются и составляют 7-8 \% от посевной площади яровой пшеницы по России, урожайность культуры остается крайне низкой и колеблется в пределах 1,5-2,0 т/га. Для обеспечения внутренних потребностей региона, повышения экономической эффективности этой культуры уровень урожайности яровой пшеницы должен составлять 3,5-4,01 т/га [2].

Известно, что корневая система яровой пшеницы отличается пониженной усвояющей способностью. Кроме того, особенностью этой культуры является сравнительно медленное развитие в начале вегетации, что связано с растянутым периодом появления вторичной корневой системы. Это ставит ее в разряд достаточ- 
но требовательных к условиям произрастания культур и способствует повышению чувствительности к неблагоприятным факторам, особенно в начальные фазы онтогенеза [3, 4, 5].

В формировании урожайности любой сельскохозяйственной культуры на втором месте после тепло- и влагообеспеченности стоят условия питания растений. Яровая пшеница имеет свои особенности в потреблении элементов питания. Накопление элементов питания в урожае культуры находится в прямой зависимости от концентрации необходимых элементов питания в пахотном слое [6].

В современных условиях минеральные удобрения являются мощным резервом повышения эффективности сельскохозяйственного производства. Повысить эффективность действия минеральных удобрений возможно, лишь создавая и поддерживая оптимальный баланс питательных элементов в почве, разрабатывая дифференцированные системы удобрения применительно к конкретным почвенно-климатическим условиям [7].

В связи с этим целью наших исследований являлось изучение сравнительной эффективности различных доз минеральных удобрений в технологии яровой пшеницы сорта Ульяновская 100 в условиях Среднего Поволжья.

\section{Материалы и методы исследований}

Экспериментальные исследования проведены на опытном поле ФГБОУ ВО Ульяновского ГАУ в 2017-2020 гг. в пятипольном зерновом сидеральном севообороте: пар сидеральный - озимая пшеница - яровая пшеница - соя ячмень. Действие удобрений испытывали на черноземе выщелоченном среднемощном. Пахотный слой участка перед закладкой опыта характеризовался следующими агрохимическими показателями: гумуса 4,5-4,7 \%, фосфора (по Чирикову)- 140-162 мг/кг, калия - 141-161 мг/кг.

Содержание подвижного фосфора определялось по методу Чирикова (извлечение 0,5 н $\left.\mathrm{CH}_{3} \mathrm{COOH}\right)$, калия - в том же растворе. Следовательно, судя по содержанию гумуса, данные почвы характеризуются низкой обеспеченностью азотом. При этом обеспеченность фосфором и калием высокая.

В опытах под предпосевную культивацию применялось комплексное, твердое, гранулированное азотно-фосфорно-калийное удобрение азофоска с содержанием NPK 16:16:16. Для получения азофоски используют экстракционную или термическую фосфорную кислоту, слабую азотную кислоту и соли калия.
Схема опыта включала 4 варианта:

1. Контроль (естественный фон)

2. $\mathrm{N}_{20} \mathrm{P}_{20} \mathrm{~K}_{20}$

3. $\mathrm{N}_{40} \mathrm{P}_{40} \mathrm{~K}_{40}$

4. $\mathrm{N}_{60} \mathrm{P}_{60} \mathrm{~K}_{60}$.

Общая площадь делянки -288 м², размещение - систематическое, повторность - трехкратная.

В опыте возделывали сорт мягкой пшеницы Ульяновская 100, который включен в Госреестр по Средневолжскому региону. Сорт характеризуется как высокоадаптивный, что позволяет формировать выполненное зерно с хорошими качественными показателями. Средняя урожайность для Средневолжского региона составляет 19,4 ц/га.

Показатели качества зерна яровой пшеницы определяли по стандартным методикам [8].

Для анализа влияния влагообеспеченности территории на продуктивность яровой пшеницы рассчитывали гидротермический коэффициент по методу Г.Т. Селянинова [9]. Вегетационный период 2017 года характеризовался избыточным количеством осадков при пониженных температурах. ГТК составил 2,1 ед. (1,0 < ГТК $\leq 2,0$ - достаточно влажно). В 2018 и 2019 годы ГТК находился на уровне 0,4 и 0,7 соответственно, что характеризует их как засушливые (0,4 $\leq$ ГТК < 0,5 - сильная засуха; 0,5 $\leq$ ГТК < 0,7 средне засушливо). В 2020 году ГТК составил 1,0 ед. (ГТК > 2,0 - переувлажнено).

\section{Результаты исследований}

Исследования показали, что внесение удобрений обеспечивало прибавку урожайности яровой пшеницы по сравнению с контролем (табл. 1).

Самая высокая прибавка урожая зерна была получена на варианте с внесением 60 кг/ га д.в. NPK - 0,73 т/га или 26,1 \%. На вариантах с дозой внесения 20 и 40 кг/га д.в. NPK урожайность зерна увеличивалась на 0,20 и 0,57 т/га или на 4-20 \% соответственно.

Математическая обработка данных, проведенная методом дисперсионного анализа, показала, что достоверная прибавка урожайности зерна яровой пшеницы обеспечивалась на вариантах с дозой внесения удобрений 40 и 60 кг/га д.в. $\left(\mathrm{HCP}_{05}-0,14-0,51\right)$.

Применение удобрений обусловило заметное улучшение качества продукции. Следует отметить, что накопление клейковины в зерне яровой пшеницы сорта Ульяновская 100 составляло от 23,5 до 27,8 \%.

Индекс деформации клейковины (ИДК) 
Таблица 1

Урожайность яровой пшеницы, т/га

\begin{tabular}{|c|c|c|c|c|c|c|c|}
\hline \multirow{2}{*}{ Вариант опыта } & \multicolumn{9}{|c|}{ Год исследований } & \multicolumn{2}{|c|}{ Отклонения от контроля } \\
\cline { 2 - 7 } & 2017 & 2018 & 2019 & 2020 & средняя & \pm & \% \\
\hline 1. Контроль & 2,74 & 2,61 & 3,26 & 2,56 & 2,79 & & \\
\hline $2 . \mathrm{N}_{20} \mathrm{P}_{20} \mathrm{~K}_{20}$ & 2,86 & 2,71 & 3,55 & 2,83 & 2,99 & 0,20 & 4,0 \\
\hline $3 . \mathrm{N}_{40} \mathrm{P}_{40} \mathrm{~K}_{40}$ & 3,29 & 2,89 & 3,92 & 3,31 & 3,35 & 0,57 & 20,0 \\
\hline $4 . \mathrm{N}_{60} \mathrm{P}_{60} \mathrm{~K}_{60}$ & 3,51 & 3,07 & 4,14 & 3,37 & 3,52 & 0,73 & 26,1 \\
\hline $\mathrm{HCP}_{05}$ & 0,35 & 0,14 & 0,51 & 0,35 & & & \\
\hline
\end{tabular}

Таблица 2

Изменение количества клейковины в зерне яровой пшеницы в зависимости от доз минеральных удобрений, \%

\begin{tabular}{|c|c|c|c|c|c|c|c|}
\hline \multirow{2}{*}{ Вариант опыта } & \multicolumn{9}{|c|}{ Годы исследований } & \multicolumn{2}{|c|}{ Отклонения от контроля } \\
\cline { 2 - 8 } & 2017 & 2018 & 2019 & 2020 & среднее & \pm & \% \\
\hline 1. Контроль & 23,3 & 23,5 & 21,6 & 25,4 & 23,5 & & 7,2 \\
\hline $2 . \mathrm{N}_{20} \mathrm{P}_{20} \mathrm{~K}_{20}$ & 25,9 & 24,5 & 22,9 & 27,6 & 25,2 & 1,7 & 14,0 \\
\hline $3 . \mathrm{N}_{40} \mathrm{P}_{40} \mathrm{~K}_{40}$ & 28,1 & 25,7 & 24,9 & 28,3 & 26,8 & 3,3 & 18,3 \\
\hline $4 . \mathrm{N}_{60} \mathrm{P}_{60} \mathrm{~K}_{60}$ & 28,0 & 27,8 & 26,2 & 29,0 & 27,8 & 4,3 & \\
\hline $\mathrm{HCP}_{05}$ & 2,8 & 1,3 & 1,7 & 2,6 & & & \\
\hline
\end{tabular}

Таблица 3

Качество клейковины яровой пшеницы в зависимости от доз минеральных удобрений, (ед. идк)

\begin{tabular}{|c|c|c|c|c|c|c|}
\hline \multirow{2}{*}{ Вариант опыта } & \multicolumn{5}{|c|}{ Годы исследований } & \multirow{2}{*}{ Группа качества } \\
\cline { 2 - 6 } & 2017 & 2018 & 2019 & 2020 & среднее & \\
\hline 1. Контроль & 90,0 & 84,4 & 86,4 & 86,7 & 86,9 & II \\
\hline $2 . \mathrm{N}_{20} \mathrm{P}_{20} \mathrm{~K}_{20}$ & 85,8 & 83,6 & 82,3 & 80,1 & 83,0 & II \\
\hline $3 . \mathrm{N}_{40} \mathrm{P}_{40} \mathrm{~K}_{40}$ & 69,4 & 84,1 & 81,9 & 75,8 & 77,8 & II \\
\hline $4 . \mathrm{N}_{60} \mathrm{P}_{60} \mathrm{~K}_{60}$ & 74,4 & 73,8 & 75,7 & 67,9 & 73,0 & I \\
\hline $\mathrm{HCP}_{05}$ & 11,5 & 8,4 & 10,2 & 14,1 & & \\
\hline
\end{tabular}

также изменялся под воздействием минеральных удобрений. ИДК на варианте с применением удобрений в дозе 60 кг/га д.в. составлял 73 единицы, что относит ее к I группе качества (табл. 2, 3).

\section{Обсуждение}

Яровая пшеница при формировании новых органов проходит 12 фаз онтогенеза. Как отмечалось выше, особенностью изучаемой культуры является медленное развитие в начальные фазы вегетации. Это связано с растянутым периодом появления вторичной корневой системы, поэтому эта культура очень чувствительна к неблагоприятным условиям развития в начальные фазы онтогенеза $[5,10]$.

Проведенные корреляционный и регрессионный анализы позволили выявить зависимости между урожайностью зерна яровой пшеницы сорта Ульяновская 100 и условиями ее формирования. Анализ данных показал, что имеется прямая связь между урожайностью и фоном питания культуры $(r=0,64)$, которая описывается уравнением регрессии $\mathrm{y}=0,0128 \mathrm{x}+2,7805$.

Влияние ГТК за период вегетации на урожайность яровой пшеницы было положительным. Связь характеризовалась как прямая слабая $(r=0,49)$. Уравнение имеет вид: $\mathrm{y}=$ $-0,4754 x+3,6272$.

При анализе результатов исследований следует отметить, что заметно увеличилось создание в пахотном слое чернозема выщелоченного, доступных фосфора и калия на 9,5-24,5 и 10-20,5 мг/кг соответственно (табл.4).

Внесение комплексных минеральных удобрений, в данном случае азофоски, способствовало более равномерному распределению питательных элементов и их комбинированному действию на растения. Обеспечивался суммированный эффект (синергизм) за счет наличия нескольких ионов, который значительно превышает действие отдельных, что создает условия для более эффективного усвоения питательных элементов растениями [11].

Нет сомнения в том, что использование 
Таблица 4

Содержание химических элементов в почве под посевами яровой пшеницы в зависимости от различных доз минеральных удобрений, мг/кг , 2019-2020 гг.

\begin{tabular}{|l|c|c|c|}
\hline $\begin{array}{c}\text { Вариант } \\
\text { опыта }\end{array}$ & Гумус, \% & $\mathrm{P}_{2} \mathrm{O}_{5}$ & $\mathrm{~K}_{2} \mathrm{O}$ \\
\hline 1. Контроль & 4,79 & 141,0 & 125,0 \\
\hline 2. $\mathrm{N}_{20} \mathrm{P}_{20} \mathrm{~K}_{20}$ & 4,82 & 150,5 & 135,0 \\
\hline 3. $\mathrm{N}_{40} \mathrm{P}_{40} \mathrm{~K}_{40}$ & 4,83 & 161,0 & 141,0 \\
\hline 4. $\mathrm{N}_{60} \mathrm{P}_{60} \mathrm{~K}_{60}$ & 4,84 & 165,5 & 145,5 \\
\hline
\end{tabular}

азофоски в технологии возделывания яровой пшеницы за счет равномерного распределения питательных элементов и улучшения их доступности для растения способствовало снижению чувствительности культуры к неблагоприятным условиям и, как следствие, росту урожайности зерна.

Следует также остановиться на содержании гумуса в пахотном слое почвы. Внесение азофоски способствовало сдвигу этого показателя в сторону его увеличения в слое почвы 0-30 см. При этом установлена тесная связь между формированием урожайности и содержанием

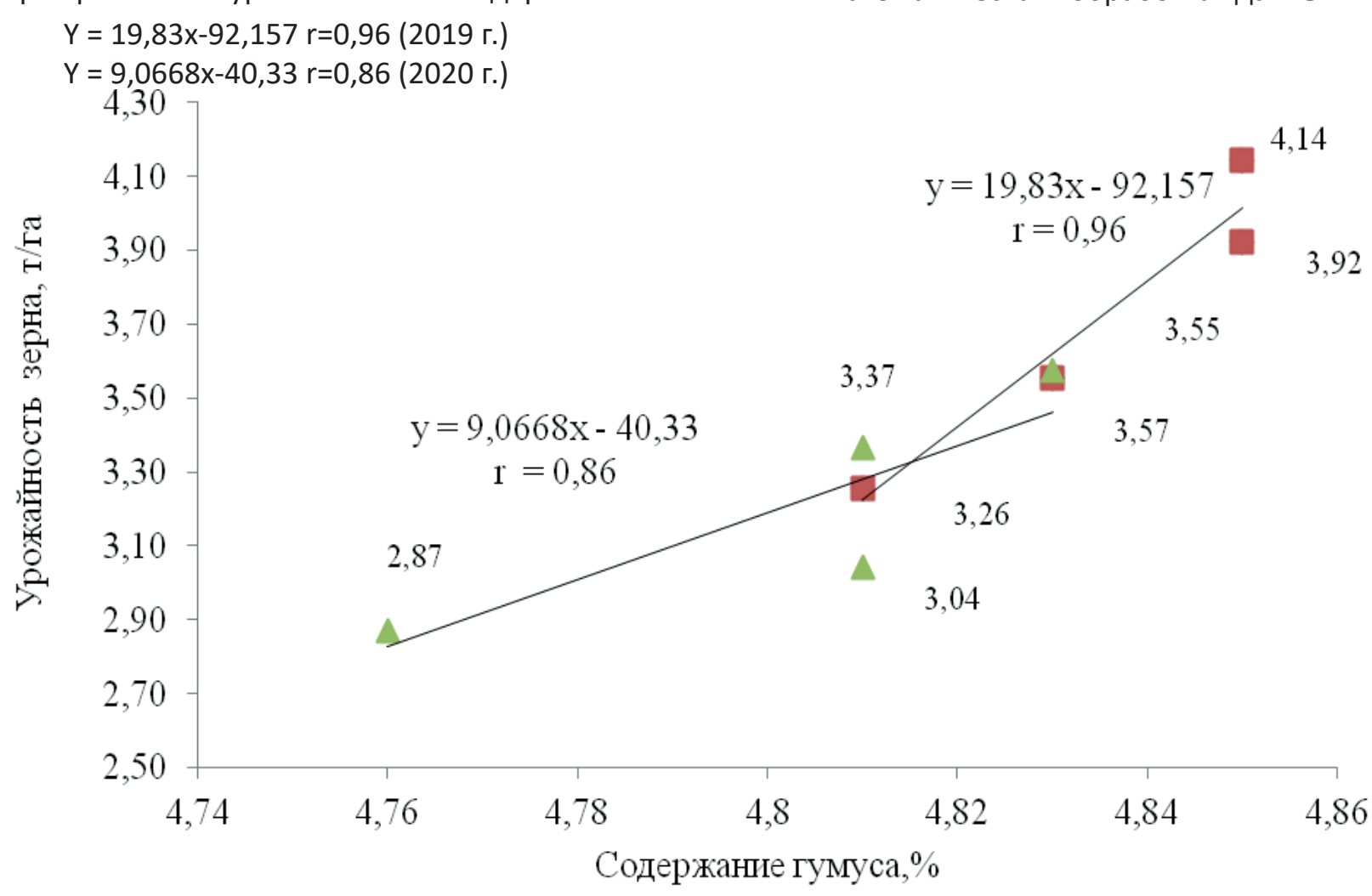

2019 г $\triangle 2020$ г

Рис. 1- Влияние содержания гумуса в почве на урожайность зерна яровой пшеницы в зависимости от различных доз внесения

tii 


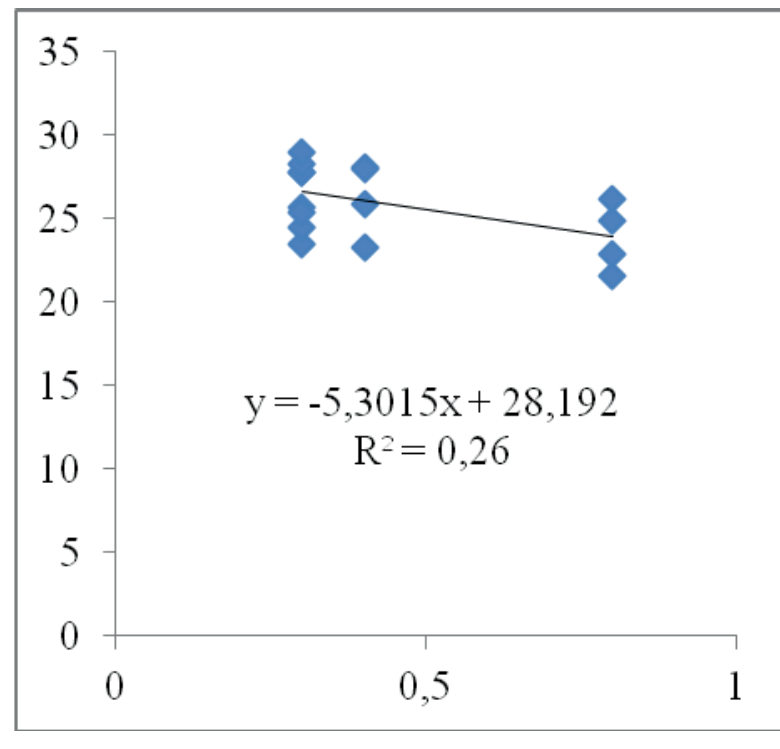

a

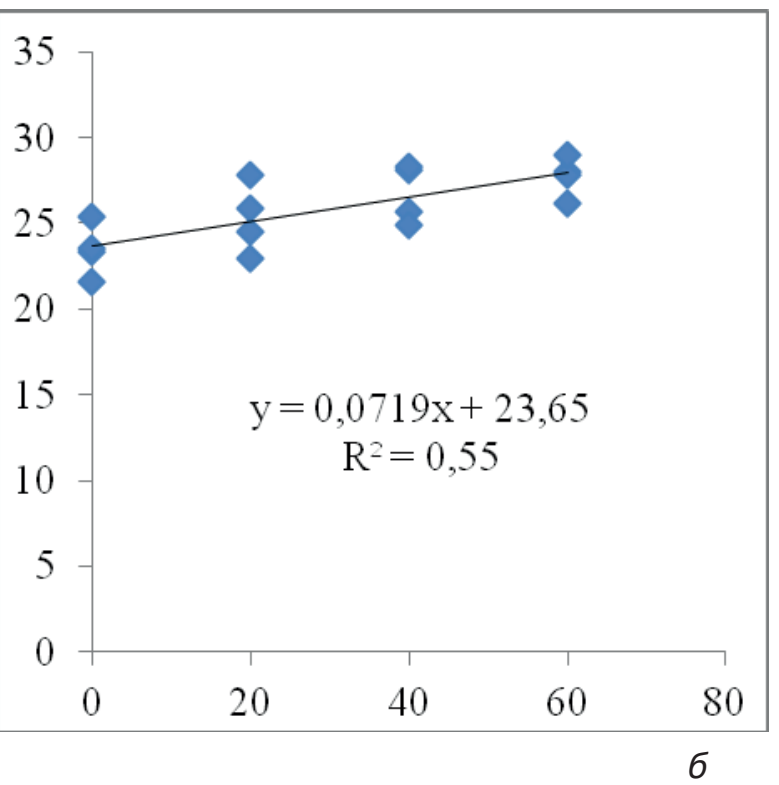

Рис. 2 - Зависимость накопления клейковины (а) от ГТК в период цветение-созревание (в) от доз минеральных удобрений

казала достоверное увеличение количества клейковины на вариантах $\mathrm{N}_{40} \mathrm{P}_{40} \mathrm{~K}_{40}$ и $\mathrm{N}_{60} \mathrm{P}_{60} \mathrm{~K}_{60}$. По сравнению с контролем содержание клейковины увеличивалось на 14,0 \% на варианте $\mathrm{N}_{40} \mathrm{P}_{40} \mathrm{~K}_{40}$ и на $18,3 \%-\mathrm{N}_{60} \mathrm{P}_{60} \mathrm{~K}_{60}$.

Существует мнение, что не клейковинные белки (альбумины и глобулины) формируются в течение 12-37 дней после колошения культуры, а клейковинные - на 12-42 день после цветения [14; 15]. При этом ученые подчеркивают, что увеличение содержания белка и клейковины происходит при засушливых условиях и повышении температуры.

Для выявления зависимостей были рассчитаны уравнения регрессии (рис. 2). Коэффициент детерминации зависимости накопления клейковины от ГТК составил $\mathrm{R}^{2}=0,26$, от условий минерального питания $\mathrm{R}^{2}=0,55$. Таким образом, регрессионный анализ показал, что накопление клейковины на 26 \% определяется сложившимися погодно-климатическими условиями периода и на 55 \% - условиями минерального питания.

Нами установлена тесная связь между массовой долей клейковины и белка в зерне яровой пшеницы сорта Ульяновская 100. Эта связь определяется уравнением регрессии: $Y=1,6303 x+7,0173$. Результаты корреляционно-регрессионного анализа показывают наличие сильной связи между этими величинами (коэффициент корреляции $r=$ $0,70)$.

Содержание белка в урожае яровой пшеницы является важным показателем качества, который определяет его питательные и технологиче- ские свойства. Несмотря на низкое содержание (9-15 \%), яровая пшеница остается главным источников белка $[16,17,18]$.

Массовая доля белка во все годы исследований находилась в пределах 10,9-12,6 \%. Применение азофоски способствовало повышению белковой продуктивности культуры. Накопление белка в урожае зерна яровой пшеницы в годы исследований изменялось от 264 (контроль) до 509 кг/ га $\left(\mathrm{N}_{60} \mathrm{P}_{60} \mathrm{~K}_{60}\right)$. Прибавка его относительно контроля составляла на варианте с внесением $\mathrm{N}_{20} \mathrm{P}_{20} \mathrm{~K}_{20}-32$ кг/га, $\mathrm{N}_{40} \mathrm{P}_{40} \mathrm{~K}_{40}-93, \mathrm{~N}_{60} \mathrm{P}_{60} \mathrm{~K}_{60}-147$ кг/га.

Согласно ГОСТ P 54478-2011 результаты упругоэластичных свойств клейковины выражают в условных единицах прибора ИДК (ед. ИДК). На вариантах 1, 2 и 3 зерно яровой пшеницы относилось к II группе качества с показателем индекса деформации от 77,8 единиц $\left(\mathrm{N}_{40} \mathrm{P}_{40} \mathrm{~K}_{40}\right)$ до 86,9 единиц (на естественном фоне удобрений) - удовлетворительная слабая.

Результаты определения качества клейковины показали, что к I группе качества (от 43 до 77 ед.) относилось зерно пшеницы, полученное на варианте с дозой внесения 60 кг д.в./га. По упругости клейковина на этом варианте относилась к I группе качества (хорошая).

\section{Заключение}

По результатам четырехлетних исследований можно сделать следующие выводы:

1. Применение минеральных удобрений обеспечивало стабильное повышение урожайности зерна яровой пшеницы. В среднем ее прибавка на варианте с внесением $\mathrm{N}_{60} \mathrm{P}_{60} \mathrm{~K}_{60}$ в сравнении с 


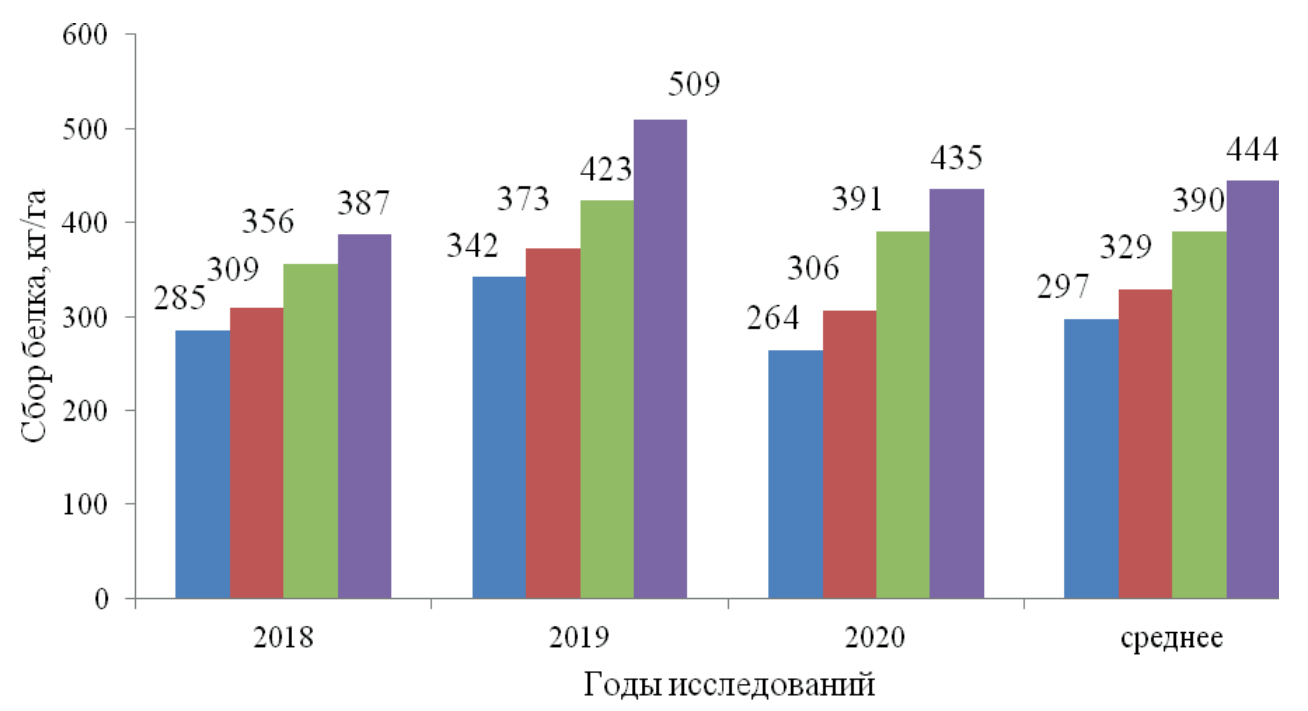

\section{Рис. 2 - Влияние минеральных удобрений на сбор белка с урожаем яровой пшеницы, кг/га}

контролем составляла 0,73 т/га.

2. Внесение минеральных удобрений способствовало увеличению в пахотном слое чернозема выщелоченного доступных фосфора (на 9,5$24,5)$ и калия (на 10,0-20,5 мг/кг) соответственно. Установлена тесная связь между формированием урожайности и содержанием гумуса в пахотном слое чернозема выщелоченного. Уравнения регрессии имеют следующий вид: $Y=19,83 x-92,157$ $r=0,96$ (2019 г.); $Y=9,0668 x-40,33 r=0,86$ (2020 г.)

3.Содержание клейковины в зерне существенно меняется от фона удобрения. Математическая обработка данных показала достоверное увеличение количества клейковины на вариантах $\mathrm{N}_{40} \mathrm{P}_{40} \mathrm{~K}_{40}$ и $\mathrm{N}_{60} \mathrm{P}_{60} \mathrm{~K}_{60}$ (на 14,0 \% и на 18,3 \% соответственно). При этом установлена тесная связь между массовой долей клейковины и белка в зерне яровой пшеницы сорта Ульяновская 100, которая описывается уравнением регрессии $\mathrm{Y}=$ $1,6303 x+7,0173, R^{2}=0,70$.

5. По упругости клейковины лучшим вариантом оказался $\mathrm{N}_{60} \mathrm{P}_{60} \mathrm{~K}_{60}-73$ ед. ИДК, то есть клейковина относилась к I группе качества (хорошая).

\section{Библиографический список}

1. Алтухов, И. А. Развитие рынка продовольственного зерна России / И. А. Алтухов // Нива Поволжья. - 2012. - № 4(25). - С. 2-10.

2. Сержанов, И. М. Оптимизация системы удобрения и технологических приемов возделывания яровой пшеницы в северной части лесостепи Среднего Поволжья : спец. 06.01.04; 06.01 .01 : диссертация на соискание ученой степени доктора сельскохозяйственных наук / Сержанов
Игорь Михайлович ; Казанский государственный аграрный университет. - Казань, 2013. - 40 с.

3. Рабинович, Г. Ю. Возделывание яровой пшеницы с применением различных схем удобрений / Г. Ю. Рябинович, Ю. Д. Смирнова, Н. А. Лукичева // Международная научно-практическая конференция ФГБНУ ВЕНИИМЗ. - Тверь : ФГБНУ ВНИИМЗ, 2015. - С. 33-37.

4. Влияние минеральных удобрений на урожайность зерна яровой пшеницы / В. Д. Абашев, Ф. А. Попов, Е. Н. Носкова, С. Н. Жук // Пермский аграрный вестник. - 2017. - № 1(17). - С.7-11.

5. Агрометеорологические условия формирования продуктивности яровой пшеницы по межфазным периодам онтогенеза / С. И. Пряхина, Ю. А. Склярова, М. Ю. Васильева, Ю. Н. Фридман // Известия Саратовского университета. 2008. - Т. 8, вып.1. - С. 22-25.

6. Клименко, Н. Н. Влияние минеральных удобрений на показатели качества зерна яровой пшеницы в условиях Иркутской области / Н. Н. Клименко, И. Н. Абрамова, Е. Н. Кузнецова // Вестник Бурятской государственной сельскохозяйственной академии им. В.Р. Филиппова. - 2019. - № 1(54). - C. 36-43. - URL: http://www.bgsha.ru/ files/images/Vestnik/1_2019/5.\%20Klimenko\%20 N..pdf

7. Сайдяшева, г. В. Эффективность минеральных, биоминеральных удобрений и биопрепарата бисолбифит на посевах яровой пшеницы в условиях Среднего Поволжья / Г. В. Сайдяшева, С. А. Захаров // Вестник Ульяновской государственной сельскохозяйственной академии. - 2017. - № 1(37). - C. 56-65. 
8. ГОСТ Р 54478-2011. Методы определения количества и качества клейковины в пшенице : введен 2013-01-01. - Москва: Стандартинформ, 2012. $-23 c$.

9. Справочник эколого-климатических характеристик г. Москвы / под редакцией А. А. Исаева. - Москва : Издательство географического факультета МГУ, 2005. - Т. 2. - 412 с. - ISBN 5-89575059-1 (в пер.)

10. Корчагина, И. А. Водный режим почвы и водопотребление яровой пшеницы по группам спелости в южной лесостепи Западной Сибири / И. А. Корчагина // Бюллетень науки и практики. 2017. - № 1. - С. 93-99.

11. Рациональное применение удобрений : пособие / И. Р. Вильдфлуш, А. Р. Цыганов, В. В. Лапа, Т. Ф. Персикова. - Горки : Белорусская государственная сельскохозяйственная академия, 2002. - 324 с. - ISBN 985-467-022-8.

12. Алабушев, А. В. Сорт как фактор инновационного развития зернового производства / А. В. Алабушев // Зерновое хозяйство России. 2011. - № 3. - C. 7-15.

13. Личко, Н. М. Стандартизация и сертификация продукции растениеводства : учебник / Н. М. Личко. - Москва: Юрайт-Издат, 2004. - 596 с.

14. Киселева, М. Ю. Формирование белко- вого комплекса зерна яровой мягкой пшеницы в лесостепной зоне Среднего Поволжья : спец. 06.01.05; 06.01.09 : автореферат диссертации на соискание ученой степени кандидата сельскохозяйственных наук / Киселева Мария Юрьевна ; Пензенская государственная сельскохозяйственная академия. - Пенза, 2004. - 16 с.

15. Розова, М. А. Влияние погодных условий на содержание в зерне яровой твердой пшеницы белка, клейковины и ее качество в условиях Приобской лесостепи Алтайского края / М. А. Розова, В. Н. Мухин // Достижения науки и техники АПК. - 2015. - Т. 29, № 8. - С. 58-61.

16. Урожайность и качество зерна яровой пшеницы в зависимости от применения гуминового и минерального удобрения / С. В. Богомазов, А. А. Левин, О. А. Ткачук, А. В. Лянденбургская // Нива Поволжья. - 2019. - № 3(52). - С. 68-73.

17. Долгополов, А. А. Яровая пшеница в Приангарье / А. А. Долгополов. - Иркутск : ИрГСХА, 2007. - 121 с.

18. Полномочнов, А. В. Яровая пшеница Предбайкалья и результаты районирования сельскохозяйственных культур / А. В. Полномочнов, И. Э. Илли, И. А. Крутиков. - Иркутск, 2009. - 288 с.

\title{
MINERAL FERTILIZERS IN SPRING WHEAT CULTIVATION TECHNOLOGY IN THE CONDITIONS OF THE MIDDLE VOLGA REGION
}

\author{
Zakharov N. G., Khayrtdinova N. A. \\ FSBEI HE Ulyanovsk SAU \\ 432017, Ulyanovsk, Novy Venets Boulevard, 1; , tel .: 8 (8422) 55-95-68; e-mail: agroec@yandex.ru
}

Keywords: spring wheat, mineral fertilizers, gluten, gluten deformation index, yield.

The paper presents results of study of the effectiveness of mineral fertilizers in the technology of spring wheat cultivation. Experimental studies were carried out on the experimental field of Ulyanovsk State Agrarian University in 2017-2020 in a five-field grain green manure crop rotation: green manure fallow - winter wheat - spring wheat - soybeans - barley. We studied change of grain yield and quality of spring wheat of Ulyanovskaya 100 variety in the experiment. Mathematical processing of the data showed that a significant increase of spring wheat grain yield was provided on the variants with fertilizer application at a dose of 40 and $60 \mathrm{~kg} / \mathrm{ha}$ of active agent, which was $0.57 \mathrm{t} / \mathrm{ha}$ and $0.73 \mathrm{t} / \mathrm{ha}$, respectively. At the same time, there was an increase of gluten amount up to $27.8 \%$ and improvement of its quality in the variant with application of fertilizers at a dose of $60 \mathrm{~kg} / \mathrm{ha}$ of active agent (73 FDM units), which assigns it to the I quality group. The performed correlation-regression analysis made it possible to reveal the relationship between the grain yield of spring wheat and the conditions of its formation. A direct relationship was revealed between the yield and the background of crop nutrition ( $r=0.64)$. It is important to note that the main factor which influences gluten accumulation in grain is mineral nutrition of plants $\left(R^{2}=0.55\right)$, the determination coefficient of the dependence of gluten accumulation on the hydrothermal index was $R^{2}=0.26$. The research results showed a close relationship between the mass fraction of gluten and protein in the grain of spring wheat of Ulyanovskaya 100 variety $\left(R^{2}=0.70\right)$. The accumulation of protein varied from 264 (control) to $509 \mathrm{~kg} / \mathrm{ha}\left(N_{60} P_{60} K_{60}\right)$ within the research years.

\section{Bibliography:}

1. Altukhov, I.A. Development of food grain market in Russia / I.A. Altukhov // Niva of the Volga region. - 2012. - № 4 (25). - P. 2-10.

2. Serzhanov, I.M. Improvement of fertilization system and technological methods of spring wheat cultivation in the northern part of the forest-steppe of the Middle Volga region: spec. 06.01.04;06.01.01: abstract of dissertation for the degree of Doctor of Agricultural Sciences / Serzhanov Igor Mikhailovich; Kazan State Agrarian University. - Kazan, $2013 .-40$ p.

3. Rabinovich, G. Yu. Cultivation of spring wheat with application of various fertilization schemes / G. Yu. Ryabinovich, Yu. D. Smirnova, N. A. Lukicheva // International scientific-practical conference of FSBSI All-Russian Research Institute of Reclaimed Lands. - Tver: FSBSI All-Russian Research Institute of Reclaimed Lands, 2015 .- P. 33-37.

4. Influence of mineral fertilizers on yield of spring wheat grain / V.D. Abashev, F.A. Popov, E.N. Noskova, S.N. Zhuk // Perm Agrarian Vestnik. - 2017. - No 1 (17). - P.7-11.

5. Agrometeorological conditions of productivity formation of spring wheat in accordance with interphase ontogenesis periods / S.I. Pryakhina, Yu. A. Sklyarova, M. Yu. Vasilieva, Yu. N. Fridman // Izvestiya of Saratov University. - 2008 - - V. 8, issue 1. - P. 22-25.

6. Klimenko, N.N. Influence of mineral fertilizers on quality parameters of spring wheat grain in Irkutsk region / N.N. Klimenko, I.N. Abramova, E.N. Kuznetsova //Vestnik of Buryat State Agricultural Academy named after V.R. Filippov. - 2019. - № 1 (54). - P. 36-43. - URL: http://www.bgsha.ru/files/images/ Vestnik/1_2019/5.\%20Klimenko\%20N..pdf

7. Saidyasheva, G.V. The effectiveness of mineral, biomineral fertilizers and Bisolbifit bioproduct on spring wheat crops in the Middle Volga region / G.V. 
Saidyasheva, S.A. Zakharov // Vestnik of Ulyanovsk State Agricultural Academy. - 2017. - № 1 (37). - P. 56-65.

8.State Standard GOST R 54478-2011. Methods for specification of the quantity and quality of gluten in wheat: introduced on 2013-01-01. - Moscow: Standartinform, 2012 .- 23p.

9. Reference book of ecological and climatic characteristics of Moscow / edited by A. A. Isaev. - Moscow: Publishing House of the Faculty of Geography of Moscow State University, 2005. - V. 2. - 412 p. - ISBN 5-89575-059-1

10. Korchagina, I.A. Soil water regime and water consumption of spring wheat by maturity groups in the southern forest-steppe of Western Siberia / I.A. Korchagina // Bulletin of Science and Practice. - 2017. - № 1. - P. 93-99.

11. Rational use of fertilizers: manual / I.R. Wildflush, A.R. Tsyganov, V.V. Lapa, T.F. Persikova. - Gorki: Belarusian State Agricultural Academy, 2002. - 324 p. - ISBN 985-467-022-8.

12. Alabushev, A. V. Variety as a factor of innovative development of grain production / A. V. Alabushev //Grain economy of Russia. - 2011. - No 3. - P. 7-15.

13. Lichko, N.M. Standardization and certification of crop production: textbook / N.M. Lichko. - Moscow: Yurayt-Izdat, 2004 .- 596 p.

14. Kiseleva, M. Yu. Formation of protein complex of spring soft wheat grain in the forest-steppe zone of the Middle Volga region: spec. 06.01.05; 06.01.09: abstract of dissertation for the degree of candidate of agricultural sciences / Kiseleva Mariya Yurievna; Penza State Agricultural Academy. - Penza, 2004 .- 16 p.

15. Rozova, M.A. Influence of weather conditions on the content of protein, gluten in spring durum wheat grain and its quality in the conditions of the Priobskaya forest-steppe of the Altai Territory/M.A. Rozova, V.N. Mukhin // Achievements of science and technology of the agro-industrial complex. - 2015. - V. 29, № 8. - P. 58-61.

16. Grain yield and quality of spring wheat depending on usage of humic and mineral fertilizers /S. V. Bogomazov, A. A. Levin, O. A. Tkachuk, A. V. Lyandenburgskaya // Niva of the Volga region. - 2019. - № 3 (52). - P. 68-73.

17. Dolgopolov, A. A. Spring wheat in the Angara region / A. A. Dolgopolov. - Irkutsk: IrSAA, 2007 .- 121 p.

18. Polnomochnov, A. V. Spring wheat of Cisbaikalia and the results of regionalization of agricultural crops / A. V. Polnomochnov, I. E. Illy, I. A. Krutikov. Irkutsk, 2009.- 288 p. 